\title{
The University Library in the Twenty-first Century
}

\author{
Clyde Hendrick
}

The author, a graduate school dean, conveys his vision of what the university library should be like in the twenty-first century. Three major topics are discussed: librarianship as a scholarly discipline; politics and the university library; the library as an active agent in the life of a university.

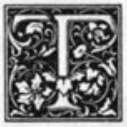

he public library is the treasure house of civilization, and the great university research library is the crown jewel of that treasure house. I have said this and believed it for many years. I'm a true friend of the library. Because I am a friend, I will take some liberties in order to tell you some tough things. Some of them you will like, and some you won't like.

I want to convey my vision of what the university library should be in the next century, just fourteen years away. Achievement of such a vision will require change, a lot of change. Therefore I do have some criticisms to impart. But they are friendly criticisms!

First, I want to present an overview of what the library can become in the next century. Based on that conception, I wish to address three topics: librarianship as a scholarly discipline, the political stance of a great university library, and the concept of the library as an active agent in the life of a university.

Please keep in mind that I am an outsider. The fact that I love libraries doesn't mean that I know much about them. But lack of knowledge doesn't preclude strong opinions. One of the few privileges that I have experienced as a graduate dean is the right to have a firm opinion on almost all matters pertaining to the university.

\section{THE VISION}

The library will still exist in the next century. It will not only exist, but it will become increasingly important in the life of the university community and the wider society. The doomsayers who predict the dispersion or demise of the library are wrong. As knowledge continues to multiply, the need for expertise-to collect, categorize, store, sort, retrieve, and advise and comfort bewildered users-will also multiply.

The library of the twenty-first century will become much more diverse in its activities. Books will undoubtedly continue to exist throughout the new century, but the media available for recording and transforming knowledge will increase substantially, perhaps in ways not now foreseen. The proliferation of media, plus the increasing specialization and complexity of knowledge, suggests that the library will become a much more complex social institution. The keepers of the treasure house, the professional librarians, will also have to become both more of a generalist and more of a specialist in the many areas that will develop. In the next century the librarian will work almost entirely with the intellect. The tedious muscle work of yesterday and today will be done by machines and nonprofessional staff. Of course the librarian will have to administer those machines and staff. Thus librari-

Cylde Hendrick is dean of the graduate school, Texas Tech University, Lubbock, Texas 79409. This paper was presented at the annual retreat of the Texas Tech Library staff in September 1985. 
ans will become administrators of the science of knowledge, or, in short, administrative/knowledge scientists.

Commensurate with this enlarged role for the librarian, the university library as a social system must become a true power center in the university community. To do so, it must assert its own status as a social system much more strongly than it does now or has in the past. At the same time, the library must permeate other sectors of the university more fully than is now the case.

In summary, my vision is that the library must move from the posture of beautiful but somewhat passive treasure house to the active role of knowledge mediator for the society. As a matter of fact, I believe that the continued viability of a coherent society depends on such a proactive role for the library. Without a central mediating force to channel the knowledge explosion, we will all be lost in the spiraling fragmentation of information chaos.

\section{THE LIBRARIAN OF THE FUTURE}

As I view the next century, the librarian will become the critical factor in the successful management of knowledge. Technology will not make your jobs obsolete. Technology will reduce the manual labor. Welcome the machines. They will free your intellects for their proper role. A good machine deserves respect for what it can do. It does not deserve love. The machines must be mastered, lest a new kind of enslavement engulfs the library profession.

The growth of knowledge will lead to ever greater complexity of knowledge. Therefore organization of that knowledge is likely to become more complex, and the physical media for storing and sorting information will become more diverse. The user's task therefore will become more difficult in two ways: (a) mastery of the physical means of getting at the information and (b) mastery of the conceptual systems for the organization of the library's store of knowledge. Once the physical and conceptual systems of organization are mastered, utilization will be enormously more efficient than it is today.
Thus "entry difficulties" into the library will increase, while "utilization difficulties" will decrease. Solution of the entry difficulties will require teaching by the librarian, and this teaching will need to be systematic and sustained. From the user's point of view, solutions to the entry problems of the machines and the abstract organization of knowledge will be high-level technical skills that must be mastered in order for students to succeed in college. As a matter of fact, in the next century, I expect that one or more courses on library instruction will be required of every college student, much like freshman English is required of all students today. Faculty will also need comparable systematic tutoring.

This development implies that one major role change for the professional librarian will be uniform movement to faculty status. Such faculty status, probably with tenure, will be of a special nature, on which I will elaborate later.

It follows that the library profession should move as rapidly as possible toward the Ph.D. as the terminal degree. I do not prejudge exactly how the doctorate for librarians should be structured, but I suspect that an interdisciplinary approach will be modal. The traditional skills courses required for an M.L.S. will still be needed, and I would expect the M.L.S. to be the entry degree into doctoral programs. I do know that the doctoral program should require some expertise in computing, science and mathematics, and research methods. Some business skills and management training will also be needed. The program should also allow for one extensive minor in some academic discipline. In addition, the research ethic should permeate the doctoral training of the librarian of the future.

So, in the year 2025 , suppose we have a brand new Ph.D. hired for a faculty position in the library. Will that person be free to set his or her own schedule for research, except for teaching a library instruction course? Not exactly. I don't have that kind of freedom as a dean. Libraries, like graduate schools, are different from academic departments-the librarian will not be able to avoid a substantial administrative 
role, and such a role requires specific duties in specific locations at specific times.

My approach to a solution is simple. The librarian will become a person of thirdsone-third administrator, one-third teacher, and one-third researcher. There are many ways of implementing this three-faceted role approach. One method is use of three-year cycles: during two years the librarian's duties would consist almost entirely of administration and teaching; during the third year the duties would consist of research, writing, and other forms of scholarly activity.

This conception may sound rather strange and farfetched. But in fact it follows rather naturally from the notion that the librarian's role must become more abstract and intellectual: the training must become more extensive and complex. The research ethos is terribly important-any discipline that cannot generate its own approaches to knowledge at a high level of skill is in danger of either becoming extinct or at best becoming a minor servant of other disciplines.

I realize that the librarian's greatly expanded role and status raises a host of issues. For example, what happens to the hierarchical authority structure of a university library? Should librarians have tenure like that of faculty in academic departments? Indeed, will the library in some sense become one giant academic department? I can't answer all questions! Indeed, some of these questions are not very interesting to me. For example, librarians work under a lot of different authority structures now - the critical item is their increased status. Once that upgrading occurs, authority structures will be rearranged to accommodate the reality of the changed library profession.

With the doctorate as the terminal degree, and with the increased levels of expertise and confidence that will go with it, the librarian can go forth boldly-even aggressively-in conceptual liaisons with faculty from the many disciplines. I don't think any of us can foresee the net results of an intellectually aggressive library profession interacting routinely with faculty from academic specialties. I do know that one social effect-over time-will be that the library's influence will permeate every nook and cranny of the university campus. In so doing, the library would, of course, become a major power center on the campus.

The notion of the library as an institution with campus power leads to my second topic, but I close this first topic by stressing the centrality of the librarian. Greatly enhanced training, as well as the status that goes with it, is the basic ground for the success of the library in the next century. Without a strong cadre of librarians with doctorates, I suspect that the library will lose ground in the influence game. And in that case we would all lose.

\section{THE POLITICS OF THE LIBRARY}

Every social system has its political features, both in terms of internal dynamics and in terms of its relations to other social systems. The library is certainly a social system, and it is certainly a political animal.

I have found it an anomaly during my academic career that most faculty have a positive attitude toward libraries, yet libraries often have little real power. There is also the attitude that libraries are merely service organizations. Perhaps most librarians buy this conception, dropping the merely, of course.

The library is a service organization; but so is every academic department! Just because you serve others doesn't mean that you are only servants. The service mentality, carried too far, leads to a kind of passive stance toward other social systems. It leads to conservatism and lack of bold initiatives but most importantly, it leads to ineptitude in the struggle for power.

All social systems within an overall system both compete and cooperate with each other. The systems that prevail in the resource struggle by definition have the most power-I don't think university libraries have been very successful in this kind of power struggle.

I have seen faculty scramble to "protect" the library during a budget crisis: there is an implicit attitude that the library is unable to scramble for itself the way a school or college can. Like a fancy "kept" 
lady, the library must be protected and cared for. It seems not to occur to many faculty that the library could be aggressive in looking out for its own needs and could administer real pain if its needs are not met.

In my view the library as a social system must become much more aggressive about university campus life. A different approach to developing political constituencies needs to be effected-the permeation concept discussed earlier is basic. Ultimately, influence rests on a rich base of complex interactions between librarians and members of other social systems on campus, but there are many other things that can be done. For example, why isn't the library always represented on every major administrative search committee? Why don't deans and chairs feel a vital interest in meeting with library staff at least once a year-to ensure that their departments and colleges are "getting their fair share" from the library? Why do deans worry sometimes about other deans encroaching on their territory, but almost never worry about the head librarian stabbing them in the back? It's not because the head librarian just happens to be a nice guy.

As a young faculty member in $1967, \mathrm{I}$ witnessed the major growth explosion of university computer centers. I wondered then, and I wonder now why computer centers did not develop as part of the library system. It seemed a natural thing to happen.

My point is not to shame you but to point out that the very worthy service orientation of the library needs to be linked to an attitude of centrality to the life of the university. Holding this attitude with pride implies seeking influence and power to command the resources to do the job right. Ultimately, beyond the persuasion and power techniques, it is a matter of values and the self-confidence of a profession. The library and the library profession need to develop a value for aggressive assertion of their importance in proportion to their actual importance to the larger society. I hope I have made it abundantly clear that in my view you are very important.

\section{THE LIBRARY AS \\ ACTIVE AGENT}

This topic is really a corollary to the other two topics. As the role of the academic librarian is enhanced and the library as a social system becomes more potent politically, the library will necessarily become a more active agent in the life of the university and the wider society. Mostly, I want to present a few ideas, some of which might be good enough to attract funding for trying them out-it is understood that most of them will cost money. But the first one is "for free."

1. The library should develop a strong proprietary/cooperative role toward new forms of information systems as these systems emerge. If it is a medium that has to do with knowledge or even "mere information," the library ought to be there ready and waiting to take it over.

2. Libraries should have extensive programs for scholars-in-residence. Such programs could range from the scholar's choice to stipulated research projects that the library wants done. I can think of no better way to start the permeation process mentioned earlier. From my point of view it was simply the aribtrariness of history that made academic departments responsible for funding research and scholarly leaves. There is no reason why libraries can't be vitally important in this role, and as the librarian's training is upgraded to doctoral status, librarians should become avid competitors for scholars-in-residence positions at other libraries.

3. A related notion involves the creation of research fellowships for faculty and doctoral students. In this arena a little goes a long way. A regular, competitive funding program would orient academic departments toward the library like nails to a magnet.

4. Beyond programs for individuals, why couldn't the library create its own institutes and centers of excellence? It could hire its own scholars to work cooperatively with the department most related to the center. I suppose the tenure issue for librarians would currently be a stumbling block, but my point is that once librarians have faculty status and full stature among the other academic disciplines, there will 
be few reasons not to hire regular academics, as needed, as members of the library staff.

5. We've all heard of midlife crises. Academics seem to have them also. One way to acquire a cadre of Ph.D.'s is to create a fellowship program for academics who want a career change. The fellowship would allow Ph.D.'s to retrain as librarians in an M.L.S. program. As in any retraining program, candidate selectivity is crucial. I conjecture that the number of faculty who would be interested might surprise you.

6. As the number of "for-charge" services increases (e.g., bibliographic searches), I suggest that academic libraries should go after off-campus business. The payoff will be more than just dollars. Over time the library would build a strong external constituency and the benefits that go with it.

7. In anticipation of the movement toward doctoral status for librarians, university libraries should begin to experiment with authority arrangements. Some delicate blend of hierarchy and collegiality will probably work best. But the knowing will only come from the doing. Change can be tough, but also fun.

8 . The electronic mail concept needs to be exploited fully for maximum contact with other universities. I've not stressed relations with other libraries, but they are important. The large changes ahead won't happen to single libraries-they will occur in all university libraries moving more or less in unison. The future progress of libraries will depend substantially on ease of communication with other libraries.

9. Finally, the chief librarian should have status and authority at least equal to a major dean and preferably higher. At- tention to such self-interested issues is important. Frankly, I don't think this issue would be that tough to win if a unified, concerted effort was made over a span of several years.

Perhaps these examples are enough to give you some idea of what I have in mind when I speak of the library as an active agent. It is a state of mind, rather than specific acts, a general orientation to be proactive rather than reactive. Such active stances on a wide range of fronts, along with transformation of the professional librarian, will, in time, make the library a dynamic center of power on the university campus.

\section{IN CONCLUSION}

I said in the beginning that I am a friend. By now, you probably feel that with a friend like me, you'll never need enemies. But that's not true. I really believe my metaphor of the treasure house. There are a few institutions that are vital to civilization-the family and church are most often mentioned-the library is a third such institution. The outer forms of these institutions change and evolve, but the central concepts endure. The quest for belonging is a sacred quest, answered by home and family. The quest for the Creator is another such quest, and the quest for knowledge and understanding of our place in the cosmos is also a sacred quest. The library is the visible symbol and one actual means of striving toward knowledge and understanding. Thus, the library is as much a matter of the spirit as it is a matter of physical place. As such, and in this sense, the library is the wellspring of our slow ascent from below toward whatever future the cosmos has in store for us. 